\title{
Lack of affordable housing finance in Malawi's major urban areas
}

\author{
E. Chapinduka Nyasulu \\ C.E. Cloete \\ E. Chapinduka Nyasulu, Department of Construction Economics, University of Pretoria, \\ Pretoria, South Africa \\ C.E. Cloete, Department of Construction Economics, University of Pretoria, Pretoria, \\ South Africa
}

\section{[Tables at bottom of the document]}

Purpose - The purpose of this research is to investigate the unaffordability of housing and limited access to finance as limiting factors to the provision of adequate housing in the urban areas of Malawi.

Design/methodology/approach - Primary data were collected by means of questionnaires followed up by semi-structured personal interviews. These interviews were conducted with all major role players in the urban housing finance industry. Secondary data were obtained through scrutiny of the stakeholders' relevant official records and reports kept at their offices. The subset of analysis was chosen to be the local authorities of Blantyre, Zomba, Lilongwe and Mzuzu.

Findings - Finance from the formal sector is accessible to fewer than 35 per cent of the urban population and less than 16 per cent of households in the major urban areas can afford an average house. No government subsidies are available for end users and development financing is limited and extremely dear. The contribution from nonconventional finance sources to housing finance is negligible.

Practical implications - It is suggested that the use of various instruments may alleviate the situation. Such instruments could include a housing tax for the implementation of subsidies, subsidies from developed countries, the formation of cooperatives and the implementation of securitisation.

Originality/value - Limited research exists on the problem of housing finance in Malawi. This paper quantifies the situation. Implementation of the recommendations will contribute to the provision of adequate housing in Malawi. 


\section{Introduction}

Malawi is a developing, land-locked country located in the central part of the Southern African sub-continent, bordering Zambia, Tanzania and Mozambique. It has a very limited industrial sector and agriculture contributes about 40 per cent of the GDP. The total area comprises 118,234 square kilometers of land and water. It had a population of 11.9 million in 2004 (CIA, 2004), which was expected to increase to 16.8 million by 2014 (Ministry of Lands, Housing, Physical Planning and Surveys, 1999, p. 1). Nearly half the population was younger than 14 years and the average life expectancy is less than 38 years (CIA, 2004). It is one of the most densely populated countries in Africa and also one of the poorest (World Bank, 2005, p. 2).

The country faces a pressing housing problem in both its urban and rural areas (Ministry of Lands, Housing, Physical Planning and Surveys, 1999, p. 1; United Nations in Malawi, 1993, p. xii). Although Malawi is one of the least urbanized countries in the world (about 17 per cent in 1998), its urban population is expected to reach about 3.8 million by 2014 (about 23 per cent of the total population) (Ministry of Lands, Housing, Physical Planning and Surveys, 1999, p. v). The major urban areas are Blantyre (the dominant commercial centre) and Zomba (the former capital city) in the southern area, Lilongwe (the capital city) in the central area and Mzuzu in the northern area. The largest city, Blantyre, has a population of more than half a million people, of whom more than 50 per cent live in informal settlements (Jambo, 2002).

The limited research done on the housing problem in Malawi includes the implication of demographic projections on urban and rural housing in the country (Chilowa, 1996); a case study addressing urbanization and urban housing in Blantyre (Manda, 1996); measures to reduce the country's poverty (Ministry of Finance and Economic Planning, 2002); the status of the property industry in Malawi (Chikafalimani, 1999); and the factors contributing to the growth of informal settlements in Blantyre (Jambo, 2002). The present study addresses the question of how available and affordable housing finance is in the major urban areas of Malawi.

\section{Data collection and research methodology}

Primary data was collected by means of questionnaires followed up by semi-structured personal interviews. These interviews were conducted with all major role players in the urban housing finance industry (the chief executive officer or delegated representative) at both the role players' head offices and other relevant divisional offices, as well as the Director or representative of the Ministries of Lands, Housing and Finance.

Secondary data was obtained through scrutiny of the stakeholders' relevant official records and reports kept at their offices. This was supplemented by critical perusal of books, publications, theses and journals on the topic under discussion. 
This research was done through a survey design (see Leedy and Ormrod, 2001, p. 196; Mouton, 2002, p. 152). The subset of analysis was chosen to be the local authorities of Blantyre, Zomba, Lilongwe and Mzuzu. These local authorities combine both urban as well as rural settings. The study was restricted to the urban settings and investigated both areas of formally planned housing and those areas where the local authorities subdivided plots and sold them for beneficiaries to construct their own houses.

\section{Sources of finance}

Financial institutions in Malawi can register under the Banking Act 44 of 1989 or under the Building Societies Act 32 of 1986. Those institutions that register under the former Act were restricted to offering products and services with short to medium term repayments. On the other hand those that had registered under the Building Societies Act were restricted to offering mortgage-related services only. These restrictions have since been relaxed and effective, since July 2004 any financial institution registered under either of the Acts can offer products and services in line with its registration license stipulations.

\section{Development finance and end-user finance}

Development finance covers the cost of land, planning application costs, township establishment costs, bulk infrastructure costs, costs of providing links and internal services, costs of constructing top structures, project development and management fees, interest charges on bridging and other loans and developer's overhead and profit. The sources of such finance ranges from own capital, long-term loan and grants/subsidies to short-term loans. Table I gives information on institutions that play a role in housing delivery in the country's major urban areas.

It is clear that participants in the housing delivery process mainly use their own financing with little use of borrowed money from financial institutions. The use of own money for housing provision in normally done by equity investors who invest their money directly into the property and reap the benefit themselves. There is no institution that relies on grants or subsidies for its development financing needs.

End-user finance is the finance that is available for prospective purchasers of housing. Table II summarizes the financial institutions in Malawi and their type of business.

Up to 2004 the New Building Society had a virtual monopoly on the provision of mortgage loans to the formal housing market. Its contribution was, however, very limited: in the 5-year period 1996-2000 only 292 loans were approved, as against 1,192 applications (Jambo, 2002, p. 51). 
The relaxation of the Banking Act that allows commercial banks to start disbursing mortgage loans has helped to offer alternatives for the Malawian citizens. Stanbic and National Bank have extended their products to include mortgages repayable in 12 years. In addition, all the other financial institutions except insurance companies provide shortterm loans, available to applicants who have some employers' guarantees or a statement from a reputable financial institution with a credit balance and good track record.

\section{Terms of mortgage lending}

Financial institutions involved in mortgage lending use investors' money to lend to those who want additional funds to finance their house purchase or construction. Their screening procedures must therefore ensure that those who are eligible to borrow such money will be able to repay it back as and when due. The sampled institutions use a number of ways to assess the risk profile of a prospective borrower (Table III).

It can be seen from the table that all the mortgage lenders require a large deposit. Collateral in the form of real property and cash cover is also a prerequisite for the amount of the loan plus other charges. As a mortgage bond is a legal instrument which gives the lender the right to foreclose on the loan in case of default, repossess the bonded or mortgaged property and sell it in the market to recover its outlays and expenses, financial institutions will only accept as collateral houses that at least meet the minimum building specifications and/or the land has secure tenure, municipal services, roads and physical structures. The number of plots that are registerable based on the Deeds Office records are 79,744 (Deeds Office's internal records: June, 2004). This means that any other property cannot be pledged as security. Furthermore, anyone wishing to get a loan for building a house as opposed to buying an existing house has to provide proof that the contractor is reputable, registered with the Malawi National Construction Industry Council and has a proven track record on similar jobs.

All institutions typically charge variable interest rates. Prevailing interest rates in the commercial and building societies for short term loans and mortgages are indicated in Table IV.

The interest rates are very high for short-term and mortgage loans and have been so for the past decade (Jambo, 2002, p. 54). This can partly be ascribed to the relatively high inflation rate: about 18 per cent in 2002 (Malawi Government, 2002) and an estimated 9.5 per cent in 2003 (CIA, 2004). The mortgage rates are especially punitive to those individuals/organisations that may want to use such loans for developing or buying property for rental purposes or for flat development, as the rate is appreciably higher than that for owner occupied single-family housing. Other finance costs are shown in Table V.

Such terms of formal financing would normally be effective in an environment where potential borrowers have enough income and/or secure jobs. This aspect is addressed in the following section. 


\section{Income profile and employment pattern}

Malawi is a relatively poor country. In 2003 the GDP per capita was about $\$ 600$ and an estimated 55 per cent of the population lived below the poverty line (CIA, 2004).

Table VI, summarizing the level of employment in the subject areas, indicate that unemployment is very high, exceeding 60 per cent in all the major urban areas.The main source of income for urban inhabitants is salaries derived from employment.Table VII indicates the relative number of people employed in different economic sectors.

The sales and services sectors (which include wholesale and retail trade activities) provide more than 38 per cent of employment in the major urban areas and also offer the best job security.

The following sub-section provides an overview of the estimated monthly income of the households as well as average expenditure profiles in the subject areas, in order to determine the affordability level of the inhabitants of the subject areas.

\section{Income and expenditure profile}

The main source of income for the residents of the urban areas is salaries, followed by informal sales. Other sources like pension or rental income do not play a significant role.Table VIII provides a breakdown of the monthly income in Blantyre. As Blantyre is the biggest city in Malawi, it can be assumed that the income in the other major urban areas will be similar, if not lower.

It is evident that most households (46.7 per cent) have an income of between 3,000 kwacha and 12,000 kwacha per month. An additional 19.1 per cent of households earn between 15,000 kwacha and 30,000 kwacha per month. The unemployed group, which includes children, the elderly and the other who do not work either by choice or due to lack of jobs, are the majority. The average income per worker in 2004 was approximately 11,500 kwacha (Jambo, 2002, p. 49, adjusted for inflation).

\section{Average monthly expenditure}

The expenditure profile is shown by way of highlighting the amount of money needed per month for basic necessities needed for an urban worker for survival (see Table IX).

The average monthly expenditure is in the region of 13,500 kwachas before adding the expenditure on rent, mortgage (if any), clothing and furniture, to mention just a few additional items. As about 65 per cent of the residents earn less than 15,000 kwachas per 
month (Table VIII), only about 35 per cent of the employed residents have any surplus income to be spent on housing and other necessities.

The implication of such a large number of people in the subject areas earning scarcely enough for basic necessities has far-reaching consequences on the housing market (e.g. Abrams, 1966, p. 143; Skinner and Rodell, 1983; Spier, 1989, p. 30). It means that such people cannot rent a decent house, let alone have savings that can be used as deposit towards a house loan. It is clear that these people are not able to benefit from the conventional housing finance system. The problem is exacerbated by the high cost of housing: The purchase cost of an average three-bedroom house in 2004 was about 850,000 kwachas, and that of a plot (stand) about 600,000 kwachas (Malawi Housing Corporation, 2004). To buy an average house would therefore require a deposit of 170,000 kwachas and repayments of about 20,000 kwachas per month over 12 years at prevailing interest rates. If a conservative assumption is made that an income in excess of about 35,000 kwachas (in 2004 terms) per month is required to provide for basic necessities as well as servicing of the mortgage loan, it means that less than 16 per cent of the households in the major urban areas of Malawi would be able to buy an average house (see Table VIII). The average mortgage payment expressed as a percentage of average salary of approximately 150 per cent illustrates in stark terms the unaffordability of housing for the average household. The ratio of average house price to annual income is more than 5, which is higher than for example India (World Bank and IFC, 2005). It is therefore not surprising that less than 50 per cent of households in the major urban areas (Blantyre, Lilongwe, Mzuzu and Zomba) live in planned areas provided by semigovernmental institutions such as the Department of Land and Housing, local authorities and the New Building Society (Nyasalu and Cloete, 2005); with the balance having to live in informal settlements.

The reasons for the high land prices have been investigated by Nyasulu and Cloete (2005). These include the insufficiency of land within city boundaries (11 per cent, 4 per cent, 2 per cent and 2.5 per cent of district land for Blantyre, Lilongwe, Zomba and Muzuzu respectively), unco-ordinated development and the high costs of services.

\section{Non-conventional finance}

There is little information on the operation of this type of finance market. It seems, however, that it plays an important role in financing basic construction and land purchases, especially in Traditional Housing Areas (i.e. areas designated in urban areas to assist low-income households to obtain accommodation, comprised of planned and unplanned settlements and plots generally leased for 99 years).

This financing type is sourced from savings and credit co-operatives. The operations of these organisations are coordinated by the Malawi Union of Savings and Credit Cooperatives (MUSCCO), which also acts as their main financial backer. MUSCCO gets its financial pool from different sources, including external donors, and in turn lends such 
funds to these credit unions under prevailing financial market conditions. According to the Ministry of Commerce and Industry records that register such Cooperatives, there were 105 credit unions in the country in 2004. These Cooperatives have a long history and have been established since the early 1980s in the cities. Though their principal mission is not to finance housing, it has been established that they do make housingrelated loans to their members. In addition, there seems to be an increased involvement by employers in the provision of financing to their members of staff to finance house purchases.

Table $\mathrm{X}$ gives some information on some of the co-operatives and other non-conventional financial institutions that offer loans.

It can be seen from the table that few non-conventional financing organisations are involved in the housing finance, and then mainly in the rural areas. It is only the credit unions that make housing-related loans in urban areas to their members. Membership to these unions as a condition for getting such loans implies that those who are not savers with such institutions cannot access such type of financing. In addition, the number of people who are accredited to such institutions are few and the amount of savings are not adequate to cover the cost of buying or building a house.

Different companies also have internal housing schemes through which they give loans to their serving members of staff to finance house purchases. The civil service housing scheme is most prominent, as it runs its Home Ownership scheme for serving civil servants from all government departments. The conditions for qualification are that the beneficiary needs to be a member of staff with remaining years of service exceeding the loan amortisation period. The existence of such schemes does not have a big impact on the availability of housing finance as relatively few people are employed in the civil service. According to the Director of Housing in the Ministry of Land and Housing, only 2000 (2 per cent) civil servants have been assisted through the scheme (Ministry of Lands and Housing internal records, 2004).

Non-conventional finance schemes still leave a lot of people outside the formal housing system, as all those who are not employed and/or do not have savings with the saving groups are not eligible to benefit. The only option available for these persons is the possibility of grants and subsidies.

\section{Grants and subsidies}

Grants and subsidies are possible when governments and/or any donor agency set funds aside for providing housing assistance to those who may be eligible to benefit based on their individual/institutional circumstances. Table XI shows institutions that are involved in infrastructure and housing delivery and whether they receive any assistance in form of subsidies from any organisation. Except for regional water boards and, on a pilot basis, local authorities, none seem to receive any subsidies from any source. 


\section{Options for housing finance}

The fundamentals that need to be addressed to ensure an efficient housing finance system are: property rights, monetary policy, economic growth and risk assessment tools, as well as capital access, risk sharing and transaction costs (Duncan, 2004; see also Chiquier, 2004; World Bank and IFC, 2005). If the fundamentals are in place, different housing finance methods that can be explored include mortgage finance, fully-guaranteed loans, payroll based systems, micro-finance methods, rental, public/private partnerships and securitisation (Coovadia, 2004). He cautions that mortgage products are not necessarily appropriate for low-income borrowers and that government facilitation is required in the context of poverty, unemployment and lack of affordability, while securitisation is only possible where a well-developed and efficient primary market exists. A variety of subsidy programmes may also be employed to help overcome the failure and incompleteness of housing finance systems and to assist selected beneficiaries to upgrade the quality of the physical housing capital or to expand home ownership as a tenure choice (Hoek-Smit, 2004; RICS, 2002, p. 35). Another factor restricting the finance of housing in developing countries is the restriction of mortgage lending to a single sector. However, no housing finance miracle can be expected when an inelastic housing supply and a high house price/income ratio exist (Chiquier, 2004, see Whitehead, 2004)).

\section{Conclusions}

Formal housing finance in Malawi is rudimentary and conditions attached to such financing exclude most potential beneficiaries, with some 65 per cent of inhabitants not being able to qualify for even limited conventional financing and less than 16 per cent able to afford a conventional house.

Those financial institutions that are involved in mortgage financing apply stringent loan criteria. All banks charge variable interest rates that are high in real terms. Commercial banks offering short-term loans provide an option to renegotiate for another short-term loan subject to successful repayment of the original loan.

The analysis of the housing market has revealed that few people can access formal finance sources, due to low income levels and a high level of insecure jobs. This situation leaves the alternative of grants and subsidies and other modes as essential if housing delivery is to improve.

Only regional water boards get some subsidies from government, based on the necessity of a project. Local authorities receive some subsidies from NGOs for upgrading basic amenities in the informal areas. It is recommended that one of the recommendations of the Commission for Africa be implemented, namely that "Growth will also require a 
massive investment in infrastructure to break down the internal barriers that hold Africa back. Donors should fund a doubling of spending on infrastructure - from rural roads and small-scale irrigation to regional highways, railways, larger power projects and Information and Communications Technology (ICT). That investment must include both rural development and slum upgrading without which the poor people in Africa will not be able to participate in growth.” (Commission for Africa, 2005, p. 13).

The fact that conventional housing finance is accessible to few people and no subsidies are available to the individual is cause for concern. It is recommended that consideration be given to a tax levy for housing from some appropriate source (similar to the tax levied on fuel sales for road maintenance) and that such money be earmarked for subsidies to qualifying families within the unemployed and low-income groups. Access to housing finance by the low/medium income groups may also be improved by encouraging group lending, inducing people to save through the formation of cooperatives which should be affiliated to MUSCO. Additional instruments that can be developed by the Government of Malawi include a more efficient mortgage finance structure, and the provision of subsidies that avoid distorting the market. Lastly, the use of off-shore securitisation may be considered to release the limited funds available for housing.

Table I Major institutional investors in housing in Malawi

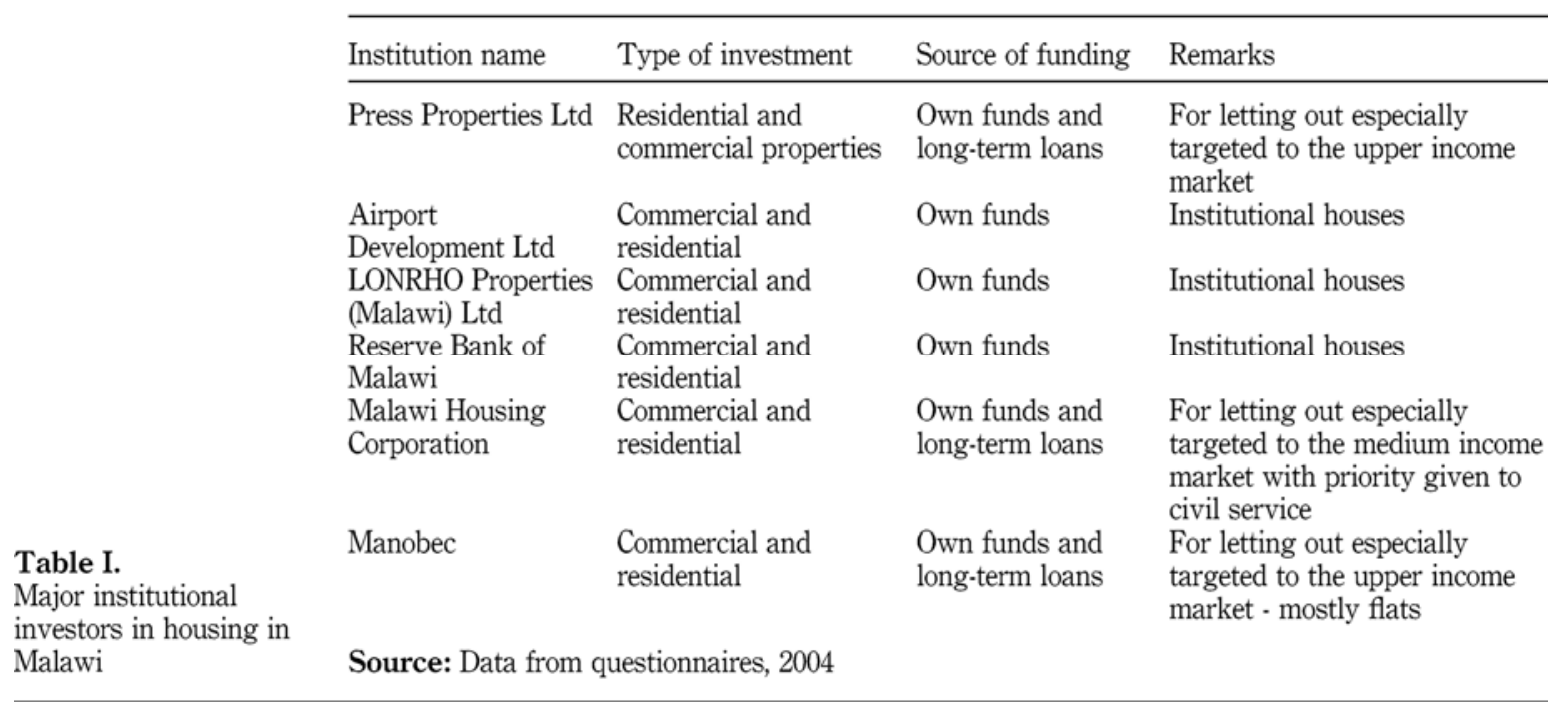


Table II Financial institutions providing development finance, 2004

\begin{tabular}{|c|c|c|}
\hline Name of institution & Type of business & Remarks \\
\hline $\begin{array}{l}\text { National Bank of } \\
\text { Malawi }\end{array}$ & Commercial bank & $\begin{array}{l}\text { Offers short and medium term loans. } \\
\text { Has also started offering mortgage services for } \\
\text { not longer than } 12 \text { years }\end{array}$ \\
\hline Stanbic & $\begin{array}{l}\text { Commercial bank and } \\
\text { leasing company }\end{array}$ & $\begin{array}{l}\text { Offers short and medium term loans. } \\
\text { Has also started offering mortgage services for } \\
\text { not longer than } 12 \text { years }\end{array}$ \\
\hline Finance Bank of Malawi & Commercial bank & Only offers short term loans of up to a year \\
\hline First Merchant Bank & Commercial bank & Only offers short term loans of up to a year \\
\hline Roita Bank & Commercial bank & $\begin{array}{l}\text { Offers short term loans of up to a year to } \\
\text { individuals. } \\
\text { May give development related loans to corporate } \\
\text { clients upon submission of a sound feasibility of } \\
\text { a project }\end{array}$ \\
\hline New Building Society & Mortgage bank & $\begin{array}{l}\text { Offers mortgage related loans of up to } 30 \text { years. } \\
\text { Has also gone into commercial banking effective } \\
1 \text { June } 2004\end{array}$ \\
\hline Malawi Savings Bank & Savings bank & $\begin{array}{l}\text { Offers short term loans repayable within } 12 \\
\text { months. } \\
\text { May give development related loans to corporate } \\
\text { clients upon submission of a sound feasibility of } \\
\text { a project }\end{array}$ \\
\hline
\end{tabular}

Source: Data from questionnaires, 2004

Table II.

Financial institutions providing development finance, 2004

Table III Terms of mortgage lending in Malawi, 2004

\begin{tabular}{|c|c|c|c|c|c|}
\hline Institution & Deposit required & Type of collateral needed & Other ways of assessing risk & Remarks & $\begin{array}{l}\text { Type of } \\
\text { interest } \\
\text { charged }\end{array}$ \\
\hline $\begin{array}{l}\text { New Building } \\
\text { society }\end{array}$ & $\begin{array}{l}20 \% \text { of value of mortgaged } \\
\text { house either under } \\
\text { construction or already built } \\
\text { house }\end{array}$ & $\begin{array}{l}\text { Land and top structure of the } \\
\text { property for which mortgage } \\
\text { hasbeen granted }\end{array}$ & $\begin{array}{l}\text { Employment situation, } \\
\text { income, credit record and } \\
\text { nature of business }\end{array}$ & $\begin{array}{l}\text { Property accepted for } \\
\text { collateral is the one that is in } \\
\text { planned location, valued by a } \\
\text { qualified valuer and has } \\
\text { proof of ownership in form of } \\
\text { title }\end{array}$ & Variable \\
\hline $\begin{array}{l}\text { National } \\
\text { Bank of } \\
\text { Malawi }\end{array}$ & $20 \%$ of property value & $\begin{array}{l}\text { Highly valued urban } \\
\text { properties with proven title }\end{array}$ & $\begin{array}{l}\text { Location of property, } \\
\text { Business track record, credit } \\
\text { history }\end{array}$ & $\begin{array}{l}\text { Value of property has to be } \\
\text { confirmed by a qualified } \\
\text { valuer }\end{array}$ & Variable \\
\hline Stanbic & $20 \%$ of property value & $\begin{array}{l}\text { Highly valued urban } \\
\text { properties with proven title }\end{array}$ & $\begin{array}{l}\text { Location of property, } \\
\text { Business track record, credit } \\
\text { history }\end{array}$ & $\begin{array}{l}\text { Value of property has to be } \\
\text { confirmed by a qualified } \\
\text { valuer }\end{array}$ & Variable \\
\hline
\end{tabular}

Table III. Terms of mortgage lending in Malawi, 2004

Table IV Interest rates applicable to short-term loans and mortgages

\begin{tabular}{lcc}
\hline Type of rate & $\begin{array}{c}\text { Charged by commercial banks } \\
(\%)\end{array}$ & $\begin{array}{c}\text { Charged by building societies } \\
(\%)\end{array}$ \\
\hline $\begin{array}{l}\text { Base rate } \\
\text { Mortgage rates: }\end{array}$ & 46 & \\
Owner occupied & 33.5 & 45.0 \\
Flats and rented houses & 46 & $\begin{array}{r}\text { Table IV. } \\
\text { Commercial properties }\end{array}$ \\
Source: Reserve Bank of Malawi, 2003 & & $\begin{array}{r}\text { applicable } \\
\text { to short-term loans and } \\
\text { mortgages }\end{array}$ \\
\hline
\end{tabular}


openUP (March 2007)

Table V Other finance costs

\begin{tabular}{|c|c|c|}
\hline Type of cost & How determined & Remarks \\
\hline Valuation fees & $\begin{array}{l}1 \% \text { of value of property but what } \\
\text { is actually paid is negotiable } \\
\text { between the parties }\end{array}$ & $\begin{array}{l}\text { Use their own professional to confirm } \\
\text { property's value }\end{array}$ \\
\hline $\begin{array}{l}\text { Costs of drawing up the } \\
\text { loan }\end{array}$ & $\begin{array}{l}\text { Varies from bank to bank. Others } \\
\text { charge up to } 1 \% \text { of loan while for } \\
\text { others it is fixed }\end{array}$ & Like an administrative fee \\
\hline Stamp duty & $0.0025 \%$ of property's value & Payable to government \\
\hline Bond registration fees & A percentage of property value & Payable to government \\
\hline Attorney fees & Negotiable between parties & To have the property registered \\
\hline Loan securing fees & Not charged at present & $\begin{array}{l}\text { When credit is in short supply in the } \\
\text { market }\end{array}$ \\
\hline
\end{tabular}

Source: New Building Society, National Bank of Malawi, Stanbic and Malawi Savings Bank, responses to questionnaires, 2004

Table V. Other finance costs

Table VI Level of employment in the subject areas

Table VII Employment by occupation in the subject areas

Table VII.

Employment by occupation in the subject areas

\begin{tabular}{lrrrr}
\hline Description & \multicolumn{1}{c}{ Blantyre } & \multicolumn{1}{c}{ Lilongwe } & \multicolumn{1}{c}{ Mzuzu } & \multicolumn{1}{c}{ Zomba } \\
\hline Total number of people & 502,053 & 440,471 & 86,980 & 65,915 \\
Employed & 162,801 & 134,328 & 33,305 & 23,257 \\
Unemployed & $339,252(66 \%)$ & $306,143(70 \%)$ & $53,675(62 \%)$ & $42,658(65 \%)$ \\
Source: National Statistical Office, 2003 & & & \\
\hline
\end{tabular}

Table VI.

Level of employment in the subject areas

\section{Table vil Employment by occupation in the subject areas}

\begin{tabular}{lccrrr}
\hline Sector & $\begin{array}{c}\text { Nation wide } \\
(\%)\end{array}$ & $\begin{array}{c}\text { Blantyre } \\
(\%)\end{array}$ & $\begin{array}{c}\text { Lilongwe } \\
(\%)\end{array}$ & $\begin{array}{c}\text { Mzuzu } \\
(\%)\end{array}$ & $\begin{array}{r}\text { Zomba } \\
(\%)\end{array}$ \\
\hline Professional and technical & 2.8 & 11.4 & 11.8 & 12.2 & 11.4 \\
Administrative and manager & 0.2 & 1.4 & 1.2 & 0.6 & 1.4 \\
Clerical and related & 1.3 & 9.3 & 8.5 & 7.5 & 9.3 \\
Sales & 5.3 & 22.3 & 23.8 & 25.4 & 22.3 \\
Services & 2.8 & 16.1 & 15.5 & 14.8 & 16.1 \\
Agriculture, animal and forestry & 82.5 & 15.5 & 18.7 & 19.2 & 15.5 \\
Production and related & 4.1 & 16.7 & 15.0 & 15.7 & 16.7 \\
Transport and equipment & 0.1 & 0.7 & 0.2 & 0.2 & 0.7 \\
Operation and laboratory & 1.1 & 6.5 & 5.1 & 4.4 & 6.5 \\
Total & 100 & 100 & 100 & 100 & 100 \\
Source: National Statistical Office, 1998 & & & & &
\end{tabular}


Table VIII Monthly income distributions (exchange rate approx. 75 kwacha to US\$1)

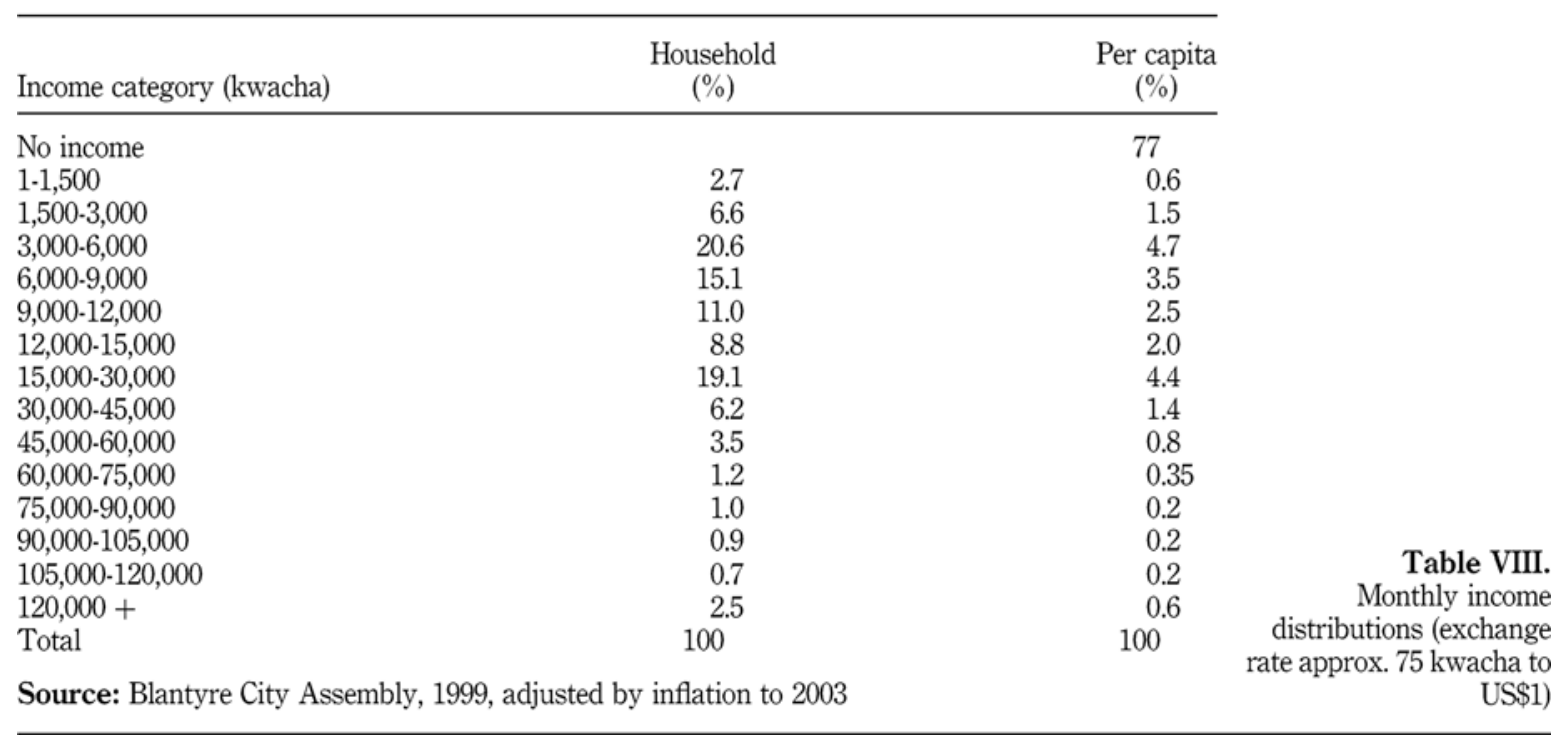

Table IX Amount spent per month per expenditure item (kwacha)

\begin{tabular}{lccccccccc}
\hline City & Food and groceries & Electricity & Water & Coal/wood & Transport & Education & Medical & Other & Total \\
\hline Blantyre & 6,932 & 988 & 926 & 413 & 1,242 & 2,459 & 433 & 1,185 & 1,4577 \\
Lilongwe & 7,098 & 1,012 & 948 & 423 & 1,271 & 2,517 & 444 & 1,213 & 1,4926 \\
Mzuzu & 6,299 & 898 & 841 & 376 & 1,128 & 2,234 & 394 & 1,080 & 1,3247 \\
Zomba & 6,913 & 986 & 923 & 412 & 1,238 & 2,452 & 432 & 1,182 & 1,4538 \\
Source: Consumer Association of Malawi, 2003, response to questionnaire & & & & & \\
\hline
\end{tabular}

Table IX.

Amount spent per month per expenditure item

(kwacha) 
openUP (March 2007)

\section{Table X Non-conventional lending institutions}

\begin{tabular}{|c|c|c|c|}
\hline Lending institution & Principal mission & Terms of lending & Remarks \\
\hline Credit unions & $\begin{array}{l}\text { Also make housing } \\
\text { related loans }\end{array}$ & \multirow{4}{*}{$\begin{array}{l}15 \text {-year loans at } 8 \% \\
\text { fixed interest rate. }\end{array}$} & $\begin{array}{l}\text { Lends to only their } \\
\text { members }\end{array}$ \\
\hline \multirow{3}{*}{$\begin{array}{l}\text { United Nations Capital } \\
\text { Development Fund } \\
\text { (UNCDF) }\end{array}$} & \multirow{3}{*}{$\begin{array}{l}\text { Housing credits for } \\
\text { rural areas in form of } \\
\text { group loans }\end{array}$} & & Run by Ministry of \\
\hline & & & Lands, Housing, \\
\hline & & & $\begin{array}{l}\text { Surveys for rural areas } \\
\text { group loans }\end{array}$ \\
\hline Habitat for Humanity & $\begin{array}{l}\text { To support construction } \\
\text { of rural houses }\end{array}$ & $\begin{array}{l}\text { Uses market lending } \\
\text { terms and community } \\
\text { participation }\end{array}$ & $\begin{array}{l}\text { Repayment pegged to } \\
\text { inflation and/or price of } \\
\text { cement }\end{array}$ \\
\hline Women World Banking & $\begin{array}{l}\text { Loans to agricultural } \\
\text { and business concerns }\end{array}$ & $\begin{array}{l}\text { Uses market lending } \\
\text { terms and community } \\
\text { participation }\end{array}$ & \\
\hline National Association of & Loans to women for any & Uses market lending & \\
\hline Business Women & kind of business & $\begin{array}{l}\text { terms and community } \\
\text { participation }\end{array}$ & \\
\hline $\begin{array}{l}\text { Malawi Rural Finance } \\
\text { Company }\end{array}$ & $\begin{array}{l}\text { Loans to agricultural } \\
\text { and business concerns } \\
\text { for rural people }\end{array}$ & $\begin{array}{l}\text { Uses market lending } \\
\text { terms and community } \\
\text { participation }\end{array}$ & \\
\hline
\end{tabular}

Source: Responses to questionnaires, 2004

Table X. Non-conventional lending institutions

\section{Table XI Number of institutions and their position in terms of subsidy assistance}

\begin{tabular}{|c|c|c|}
\hline Institution & Form of subsidy & $\begin{array}{l}\text { Organisation providing the } \\
\text { subsidy }\end{array}$ \\
\hline Malawi Housing Corporation & None & \\
\hline Press properties & None & \\
\hline Manobec & None & \\
\hline Local authorities & $\begin{array}{l}\text { They get some subsidies on a } \\
\text { pilot basis for upgrading the } \\
\text { chosen informal settlement This } \\
\text { is done through the provision of } \\
\text { basic amenities, mainly water, } \\
\text { earth roads and ventilated } \\
\text { improved pit latrines }\end{array}$ & $\begin{array}{l}\text { Mainly NGOs, most } \\
\text { prominently being Plan } \\
\text { International, Action Aid, } \\
\text { UNICEF and UNDP }\end{array}$ \\
\hline $\begin{array}{l}\text { Lilongwe and Blantyre Water } \\
\text { Boards }\end{array}$ & None & \\
\hline $\begin{array}{l}\text { Southern, Northern and Central } \\
\text { Region Water Boards } \\
\text { ESCOM }\end{array}$ & $\begin{array}{l}\text { Get financing for their } \\
\text { infrastructure provision } \\
\text { None }\end{array}$ & $\begin{array}{l}\text { Malawi Government through } \\
\text { the Department of Water }\end{array}$ \\
\hline
\end{tabular}

Table XI.

Number of institutions and their position in terms of subsidy assistance 


\section{References}

Abrams, C. (1966), Housing in the Modern World: Man's Struggle for Shelter in an Urbanising World, Faber and Faber, London.

Blantyre City Assembly (1999), Blantyre City Assembly Urban Structure Plan; Draft Background Study Report, Blantyre City Assembly, Blantyre.

Chikafalimani, S.H.P. (1999), “Overview of the property industry in Malawi”, unpublished MSc treatise, University of Pretoria, Pretoria.

Chilowa, W. (1996), "Demographic projections and their implications for urban and rural housing in Malawi”, unpublished MSc treatise, University of Malawi, Zomba.

Chiquier, L. (2004), “Lessons from best international practices”, paper presented at the 25th World Congress of the International Union for Housing Finance, Brussels, 22-25 June.

CIA (2004), The World Factbook - Malawi, available at:

www.cia.gov/cia/publications/factbook/geos (accessed 24 March 2005).

Commission for Africa (2005), "Our common interest”, report of the Commission for Africa, available at: www.commissionforafrica.org/english/report (accessed 24 March 2005).

Coovadia, C. (2004), “Global and regional trends: africa perspective”, paper presented at the 25th World Congress of the International Union for Housing Finance, Brussels, 22-25 June.

Duncan, D. (2004), “The fundamentals of an efficient housing finance system”, paper presented at the 25th World Congress of the International Union for Housing Finance, Brussels, 22-25 June.

Hoek-Smit, M.C. (2004), "New wines in old bottles? Finance policies for affordable housing in emerging economies”, paper presented at the 25th World Congress of the International Union for Housing Finance, Brussels, 22-25 June.

Jambo, E.K. (2002), "Factors contributing to the increase of informal settlements in the city of Blantyre”, inpublished MSc (Real Estate) treatise, University of Pretoria.

Leedy, P.D., Ormrod, J.E. (2001), Practical Research: Planning and Design, 7th ed., Merrill Prentice Hall, Englewood Cliffs, NJ.

Manda, M.A.Z. (1996), Urbanisation and Urban Housing in Malawi: The case of Blantyre City, International Training Programme in Population and Sustainable Development, University of Botswana, Gaberone. 
Malawi Government (2002), “Monthly economic report, May and June 2002”, available at: www.ma;awi.gov.mw/finance/nec/er05062002.htm (accessed 24 March 2005).

Malawi Housing Corporation (2004), Malawi Housing Corporation Internal Reports on Housing Demand, Malawi Housing Corporation, Blantyre.

Ministry of Lands, Housing, Physical Planning and Surveys (1999), National Housing Policy, Malawi Government, Lilongwe.

Ministry of Finance and Economic Planning (2002), Ministry of Finance and Economic Planning Poverty Reduction Strategy Paper, Malawi Government, Lilongwe.

Mouton, J. (2002), How to Succeed in your Masters and Doctoral Studies: A South African Guide and Resource Book, Van Schaik, Pretoria.

Nyasulu, E., Cloete, C.E. (2005), "Causes of inadequate housing in Malawi's major urban areas”, paper presented at the XXXIII IAHS World Congress on Housing: Transforming Housing Environments through Design, Pretoria, 27-30 September.

Reserve Bank of Malawi (2003), Reserve Bank of Malawi Monthly Economic Review, December, Department of Research and Statistics, Reserve Bank Publications, Lilongwe.

RICS (2002), RICS Global Manifesto 2002, RICS, London.

Skinner, R., Rodell, M.J. (1983), People, Poverty and Shelter: Problems of Self-Help Housing in the Third World, Methuen and Co. Ltd, London,

Spier, A. (1989), Beating the Housing crisis: Strategic Options for the next Two Decades, Human Sciences Research Council, Pretoria.

United Nations in Malawi (1993), Ministry of Women and Children and Community Services, UNCEF and UNDP, Malawi Government, Lilongwe.

Whitehead, C. (2004), “Financing affordable housing”, paper presented at the 25th World Congress of the International Union for Housing Finance Brussels, Belgium, 22-25 June.

World Bank (2005), “An independent review of World Bank support for capacity in Africa: the case of Malawi”, Document 32907, 17 March 2005.

World Bank and IFC (2005), "Housing finance in emerging economies. Technical brief to board of the World Bank Group”, 9 June 2005, available at: http://siteresources.worldbank. org/FINANCIALSECTOR/5141941101934206838/20541858/HFTB060205.ppt (accessed 18 September 2005). 
National Statistical Office (2002), National Statistical Office Population and Housing Census Analytical Report, Malawi Government, Zomba.

National Statistical Office (2004), National Statistical Office Quarterly Statistical Bulletin, Malawi Government, Zomba, March.

\section{Corresponding author}

C.E. Cloete can be contacted at: chris.cloete@up.ac.za 